\title{
CHARLEMAGNE'S ROAD, GOD'S THRESHING FLOOR; COMPREHENDING THE ROLE OF HUNGARY IN THE FIRST CRUSADE
}

\author{
JAMES PLUMTREE \\ American University of Central Asia (AUCA) ${ }^{1}$ \\ jamesplumtree@googlemail.com
}

\begin{abstract}
The violence that occurred in the medieval Kingdom of Hungary at the start of the First Crusade in the medieval Kingdom of Hungary appears in several of the works produced in the outpouring of literature that followed the capture of Jerusalem. Examination of these writings reveals ecclesiastic authors inserting exegesis, exempla, allusion, and affabulation into their retellings. These inclusions countered criticism of those who fled, stressed communal Benedictine values, and crafted an understanding of the events and the new Crusade movement. Study of these depictions of the chaotic events in the semi-Christianized territory on the periphery of the Latin West reveals the development in presentation and reception of the crusade.
\end{abstract}

Keywords: First Crusade, Kingdom of Hungary, narrative history, Peter the Hermit, Rule of St. Benedict

In their accounts of the First Crusade, monastic authors inserted theological exegesis into their retellings of the outbreak of violence in the medieval Kingdom of Hungary. ${ }^{2}$ The bloodshed in Hungary provided them with the opportunity to counter criticism from those who had fled and to craft an understanding of the events and the new Crusade movement for their audiences.

Since scholarly findings and answers are shaped by questions and aims, the textual constructions of Hungary have gone unnoticed. An aim for a chronology of the First Crusade meant these sources were mined for details. To construct a single comprehensive narrative, these historical texts were sliced together with little comment on the hazards of relying on single witnesses for certain passages. ${ }^{3} \mathrm{~A}$ focus on regional and national history has likewise resulted in a cutting-and-pasting of sources, similarly overlooking the inherent structures in which the material was embedded. ${ }^{4}$ Crusader studies, predominantly focused on the historical events, long dismissed offhand the voluminous rewritings by non-participants. Recent studies of disregarded historical narratives have revealed telling omissions and insertions. ${ }^{5}$ Rather than looking for the historical event that is not visible, by viewing such texts as unique entities produced by 
individuals with particular aims and orientations, it is possible to eavesdrop on specific voices, interpretations, arguments, anticipate the response of an intended audience, and note the discussion in which they participated. Just as the map is not the territory, the historical text is not the historical event; placing external values and aims onto such sources silences what they had originally intended to do. Approaching these historical sources as literary creations, it is possible to see how the authors provided the events of Hungary with a role in their narratives of the First Crusade.

\section{Context of the First Crusade: The Historical Event}

Pope Urban, heeding pleas from Byzantine envoys, pledged military assistance against the Seljuqs. He made clear whom he wished to depart eastwards on the Feast of Assumption (15 $5^{\text {th }}$ August 1096).

\footnotetext{
We were stimulating the minds of knights to go on this expedition, since they might be able to restrain the savagery of the Muslims by their arms and restore the Christians to their former freedom: we do not want those who have abandoned their world and have vowed themselves to spiritual warfare either to bear arms or to go on this journey; we go so far as to forbid them to do so. ${ }^{6}$
}

Knights could finance themselves and make use of the recent harvest on route; monks, of whom the eleventh century had witnessed a sizable number of knights repenting to join, had their own higher battles to fight. ${ }^{7}$ Support, however, was broader than Urban intended: in addition to monks who went against the prohibition there were also women and children, the young and old. The lesser nobility (Walter Sans-Avoir, Count Emicho), and minor religious figures (Peter the Hermit, Folkmar, Gottschalk), attempted to lead armies through Hungary before the set date and before the contingent led by Godfrey of Bouillon.

Hungary was relatively new to Christianity. ${ }^{8}$ A century earlier, the ruling elite, though tempted by Byzantine missionaries, opted for Catholicism. Foreign dignitaries and churchmen appeared in town centers. Stringent laws and church councils aimed to Christianize a kingdom that included Jews, Muslims, and the semi-nomadic Pechenegs (whose beliefs varied between paganism, Christianity, and Islam). To assist the new faith, several members of the royal family were canonized. Questions remain as to what extent the country retained a 'pagan' identity and whether such a culture (or memory thereof) was a literary topos or a reflection of reality. For those travelling from the Latin West, Hungary would have appeared noticeably different. The opening of the Roman road system in Hungary for pilgrims, permitting a cheaper - and supposedly safer - route to 
Jerusalem than by sea, created an impression in the West of an emerging Christian kingdom increasingly central to Christendom. ${ }^{9}$ The kingdom though relied on non-Christian elements: the monarch employed Pechenegs to convey information from the near-uninhabited borderlands, while the city centers (and the kingdom) were enriched by Jewish and Muslim traders. ${ }^{10}$ The kingdom's frontier position with regards to Byzantium and the eastern steppe similarly would have made Hungary appear different to those from the West.

In 1096, success in traveling through the kingdom varied; disputes led to violence, closed borders, battles, and the subsequent returning home of many participants. Scholarship has shown that the earliest force that attempted the journey, led by Peter the Hermit and Walter Sans-Avoir, contained more knights and more structure (and leadership) than the frequent popular labels 'People's Crusade' and 'Peasants' Crusade' would suggest. ${ }^{11}$ The army that obeyed Urban's commands, led by Godfrey of Bouillon, took the overland route presumably to avoid Italian seaports because he had previously sided against the Church in the Investiture Contest (and possibly participated in the 1084 seizure of Rome). Members of this contingent became significant figures in the First Crusade, particularly Godfrey, the first ruler of the new Kingdom of Jerusalem. ${ }^{12}$

\section{The Texts of the First Crusade: The Historical Sources}

The capture of Jerusalem and need to support the fledging territories resulted in an unparalleled outpouring of literature. ${ }^{13}$ An early response to the events in Hungary, the annal entry for 1096 in Bernold of Blaisen's Chronicon, is possibly an interpolation following the schemata outlined by later texts (described below). ${ }^{14}$ The events, and the crusading movement itself, lacked a specific terminology to categorise it as a crusade in late-eleventh and early-twelfth centuries. ${ }^{15}$ The participants themselves appear to have partly used the language, concepts, and rules of pilgrimage - particularly with regards to abstaining from sexual behavior (including marital) - though this vocabulary features in recorded oral retellings at a later stage by participants, evidence of which is fragmented (and often worked into a larger narrative by a monastic author). ${ }^{16}$

The earliest texts concerned with the First Crusade are frequently labelled 'eyewitnesses.' The first, and most notable, is the anonymous Gesta Francorum et aliorum Hierosolimitanorum, completed after victory at Ascalon in 1099. It is not mere reportage, but a conscientious construction by an author - whom scholarship disagrees whether he was a religious clerk or a secular knight (or somewhere in between) - with aims, biases, and narrative constraints. ${ }^{17}$ The other texts also labelled 'eyewitness,' having been produced by participants, draw upon versions (or sources) of the anonymous Gesta. ${ }^{18}$ The label is unhelpful: in addition 
to the obvious concern that these participants recorded details they could not have observed, the term 'underplays the narratological ambition and substantive complexity within the texts. ${ }^{19}$

Another, later, text can also be regarded as an 'eyewitness.' The Historia Ierosolimitana, by a non-participating monk later given the name Albert of Aachen, has also long been subjected to scholarly neglect. The author, whom 'various hindrances' prevented his desire to participate, set about after the return of participants of the successful crusade compiling a history 'as if I were a companion in the journey, if not with my body then with all my heart and soul. ${ }^{20}$ This incorporation of oral history has led to the scholarly assessment '[a]lmost as good' as the aforementioned 'eyewitness' reports, ${ }^{21}$ the text however has the potential of revealing changes in aims and interpretations. The original intention, recording the journey to Jerusalem, is reached at the end of the first six books of the work; this section, dated to the start of the twelfth century, may have existed independently of the later expansion of a further six books covering 1099-1119.22 As with the earlier sources discussed, this author's work, produced in a monastery soon after the events, may usefully be given the label 'first generation' to remove any stigma concerning value. ${ }^{23}$

The 'second generation' consists of Northern French monks rewriting the Gesta Francorum from c. 1105 onwards. Armed with well-equipped monastic libraries, these non-participating Benedictines engaged in 'theological refinement': inserting into the 'eyewitness' account scriptural and monastic exegesis. ${ }^{24}$ Two such works are Robert the Monk's Historia Ierosolimitana, and Guibert of Nogent's Dei Gesta Dei Per Francos. As with the label 'eyewitness,' the qualities of these texts have been overlooked owing to a scholarly assertion that these texts were propaganda exercises intended to win support for the new territories in the east. ${ }^{25}$ In addition to being unlikely, the interpretation is extremely reductive: rather, the texts were meant to show the deeper meaning of the historical event - beyond what was seen by the eyewitnesses. ${ }^{26}$ These Latin works, with biblical and classical allusions (and varying degrees of versification) aimed to show the divine hand in human history to other well-educated ecclesiastics. Though countering criticisms of the crusade levelled by those who returned disillusioned, these writings made insertions to emphasise and reiterate Benedictine values, for war 'was among the most useful tools in the monk's meditative arsenal, and its language and symbolism were intimately woven into his identity. ${ }^{27}$ These authors used the correlation between sexual behavior and defeats in battle to stress to fellow ecclesiastics moral conduct, and, in their depictions of the itinerant Peter the Hermit, uphold the judgments of their Rule of St. Benedict, the precepts by which Benedictine monastics abide. Having changed the character of the 'eyewitness' source, these texts cannot be mere reserve repositories of fact; they should rather been seen as textual devices by which a community understood itself and attempted to improve itself. These were products of a 'textual community' in which these 
works, 'often re-performed orally,' '[t]he outside world was looked upon as a universe beyond the revelatory text; it represented a lower level of literacy and by implication of spirituality, ${ }^{28}$ Though these retellings of the Gesta Francorum shared an exegetical-expanded narrative of the recent capture of Jerusalem, the different choices in biblical allusions show that while they shared the same motivation, they lacked a shared design. ${ }^{29}$ Each text shows a particular author, and, potentially, a particular audience.

The other texts analysed provide illuminating comparisons with the 'second generation' French Benedictines. One is the aforementioned Historia Ierosolimitana (of which the later six books, covering 1099-1119, is likely datable to 1120s-30s), whose later references to the First Crusade shows a change in perception likely shaped by continued involvement in a monastic 'textual community.' The change from boisterous anecdotes and colourful memories to a more restrained account may indicate Albert's liminal position as both a first and generation author writing immediately and then decades later the events. ${ }^{30}$ Another, surviving in a single manuscript, are additions made by an anonymous author after 1118 to Gilo of Paris' Historia Vie Hierosolimitane, itself a versification of Robert the Monk's expansion of the Gesta Francorum. The alterations made by a figure labelled the 'Charleville Poet' show a conscientious focusing on the local hero Godfrey of Bouillon (Bouillon being approximately twenty kilometres from Charleville). These additions, likely made by a teacher, include a new opening that includes the events in Hungary, suggest that the incidents were considered so important a feature of the narrative of the First Crusade that its absence required correcting. ${ }^{31}$ These three variants of the First Crusade narrative provide an illuminating contrast to the Benedictine versions.

The following studies do not examine the narratives in strict chronological order. This design emphasises that each account is a self-contained stand-alone work produced with individual intentions by an author contributing to a larger outpouring of literary creations concerned with the First Crusade. Examined together, the sources show that with the placing of Hungary in each text by each author for a particular purpose, the kingdom became an increasingly significant feature in comprehending the crusading enterprise.

\section{Regulating a Hermit while Praising Monks: Robert the Monk's Historia Iherosolimitana, the Rule of St. Benedict, and the Gesta Francorum}

The depiction of the route through Hungary in Robert the Monk's Historia Iherosolimitana shows the narrative of the Gesta Francorum being reshaped for a monastic audience. Details from the Rule of St. Benedict are inserted to reiterate Benedictine values. 
The Gesta Francorum is brief regarding the attempted journey through Hungary. Owing to having taken another route, the anonymous author seemingly combines the separate forces of Peter the Hermit and Godfrey of Bouillon and does not mention the violence.

The Franks ordered themselves into three armies. One, which entered into Hungary, was led by Peter the Hermit and Duke Godfrey, Baldwin his brother and Baldwin, count of Hainault. These most valiant knights and many others (whose names I do not know) travelled the road which Charlemagne, the heroic king of the Franks, had formerly caused to be built to Constantinople. ${ }^{32}$

While factual details are muddled in the account - Walter Sans-Savoir's force, despite entering Hungary earlier, appears later in anonymous' narrative, and Peter and Godfrey are incorrectly claimed to be the first to reach Constantinople ${ }^{33}-$ the intention of the anonymous author is clear. The inclusion of the Charlemagne association subtly praises the monarch's descendant, Godfrey, in the minds of the audience familiar with the lineage.

Robert the Monk inserted into the Gesta Francorum more knowing allusions. The Benedictine monk, ordered by his abbot 'to add the beginning which was missing and improve its style for future readers,' kept many of the details (and errors) of the source while inserting Biblical and theological material to provide his community with a more acceptable reading of the events. ${ }^{34}$

The itinerant Peter the hermit is depicted differently: he is presented as a hypocritical glutton valued by the laity above the ecclesiastical hierarchy.

At that time there was a man called Peter, a famous hermit, who was held in great esteem by the lay people, and in fact venerated above priests and abbots for his religious observance because he ate neither bread nor meat (though this did not stop him enjoying wine and all other kinds of food whilst seeking a reputation for abstinence in the midst of pleasures). ${ }^{35}$

Robert, a Benedictine monk residing in a monastery, has included a detail from the Rule of St. Benedict. According to the rule of his order, there are four types of monks: two acceptable (cenobites, living in a monastery serving under a rule; anchorites, hermits schooled in a monastery but functioning alone), two condemnable (sarabaites, who having no rule nor experience, go in pairs or threes following their desires and forbidding what they do not want to do; and gyrovagues). The last group, the worst,

spend their whole lives lodging in different regions and different monasteries three or four days at a time, always wandering and never 
stable, serving their own wills and the lure of gluttony, worse than sarabaites in every way. It is better to kept silent that to discuss the utterly wretched monastic ways of all these people. ${ }^{36}$

Robert's insertion reveals an official monk pouring scorn on a figure the Benedictine Rule would categorise as a dangerous inferior. For an author and audience whose lives were regulated by the Rule of St. Benedict, this detail would act as a confirmation of their values.

Godfrey is likewise provided with more details. After noting that Peter had gathered 'a not insignificant force' that 'set off via Hungary,' Robert presents the two joining forces. Robert clarifies to his French audience that Godfrey was of French stock (being the son of Eustache of Boulogne), and presents him as a hero in a chanson with a telling slant.

Godfrey was handsome, of lordly bearing, eloquent, of distinguished character, and so moderate with his soldiers as to give the impression of being a monk rather than a soldier. However, when he realised that the enemy was at hand and battle was imminent, his courage became abundantly evident and like a roaring lion he feared the attack of no man. What breastplate or shield could withstand the thrust of his sword? ${ }^{37}$

The obedience and discipline of a soldier was an apt metaphor for the rigid life of a monk; crusaders, regarded as lay pilgrims that temporarily took monastic vows and habits, likewise had allegorical connotations for a monastery. Some in Robert's ecclesiastical audience would have left behind a background in warfare for the religious life; others would nostalgically remember boyish ambitions to imitate the deeds of knights in chanson. Robert uses the detail to paradoxically remind them that Godfrey is only a knight, not a monk; as with the criticism of Peter, this insertion reiterates to an audience the values to which they adhere.

While Robert's reworking provides no new information about the historical journey through Hungary, the insertions reveal a Benedictine monk creating a deliberate contrast between Peter and Godfrey to explain their different outcomes. Peter's hypocrisy sets him up for a fall; Godfrey's monastic characteristics explain his success.

All this is done using the Rule of St. Benedict, a text that Robert's audience would have known and mentally assimilated. Hearing the details of the Historia Iherosolimitana passage regarding Hungary, Robert's audiences would have heard a didactic history lesson confirming to them the values and rules of their order. 


\section{Dealing with Defeat, Explaining Victory: Bernold of Blaisen's Chronicon and Guilbert of Nogent's Gesta Dei Per Francos}

The entry for 1096 in Bernold of Blaisen's Chronicon shows usage of Old Testament motifs to explain the failed journeys through Hungary. Written after the successful capture of Jerusalem, the Guibert of Nogent's Gesta Dei Per Francos employs the same conception to explain why some failed and some succeeded. As with Robert the Monk, the two authors, both Benedictines, use the values of their order to emphasise its standards.

The entry for 1096 in the Benedictine annalist Bernold of Blaisen's Chronicon includes a seemingly contemporary record of the failed journeys across the land. Bernold noted 'an innumerable multitude of poor people leapt at that journey too-simple-mindedly, and they neither knew nor were able in any way to prepare themselves for such danger. ${ }^{38}$ As modern scholarship has shown that this early force was wealthier and better organised than claimed, ${ }^{39}$ Bernold constructed a reason for the defeat from his distant monastery.

\footnotetext{
It was not surprising that they could not complete the proposed journey to Jerusalem because they did not begin that journey with such humility and piety as they ought. For they had very many apostates in their company who had cast off their monastic habits and intended to fight. But they were not afraid to have with them innumerable women who had criminally changed their natural clothing to masculine clothing with whom they committed fornication, by doing which they offended God remarkably just as had also the people of Israel in former times and therefore at lengthy, after many labours, dangers and death, since they were not permitted to enter Hungary they began to return home with great sadness having achieved nothing. ${ }^{40}$
}

The motif of a lawless mob fitted with the monastic condemnation of life outside an order. Monks abandoning their habits, women dressing as men, sexual misbehavior, and such, is regarded through the Old Testament theme of defeat in battle as divine condemnation..$^{41}$ The chronicle format, designed to reveal the workings of God in history, here also upholds Urban's prohibition of the clergy amongst general monastic disdain for the outside world.

Guibert of Nogent's Gesta Dei Per Francos used such events for a new purpose following the capture of Jerusalem. With the advantage of hindsight, Guibert's text contrasts the failure of Peter's forces in Hungary with those of led by Godfrey; the events are presented as a premonition of the enterprise as a whole. The text is designed for performance: the message of the biblical quotation use to describe the misplaced zealousness of the early participants is reinforced by the claim that the children of the poor, heading to the Holy Land, enquired at each city and each castle whether they had reached Jerusalem. ${ }^{42}$ This mode of tell- 
ing reflects the literate elite, believing themselves chosen, distancing themselves from the uneducated masses deemed wayward; the claim that, unlike themselves, the poor cannot recognise 'true' signs because of their lack of knowledge does not need to be spelt out, for Guibert and his audience would share such an assumption. The retelling would have such a notion reconfirmed.

Guibert's depiction of Peter is one such example of the narrative being crafted to fit the attitudes he shared with his audience. In a pointed insertion, Guibert makes it clear who are the real figures of authority in the journey to Jerusalem.

While the leaders, who needed to spend large sums of money for their
great retinues, were preparing like careful administrators, the common
people, poor in resources, but copious in number, attached themselves to
a certain Peter the Hermit, and they obeyed him as though he were the
leader, as long as the matter remained within our own borders. ${ }^{43}$

The last four words are a knowing wink concerning what will follow. The repeated stating of uncertainty knowingly cast aspersions on Peter, providing 'a polished sneer from a Benedictine monk to an itinerant preacher' 44 that insinuates the common folk follow Peter because of their ignorance.

\begin{abstract}
If I am not mistaken, he was born in Amiens, and, it is said, led a solitary life in the habit of a monk in I do not know what part of upper Gaul, then moved on, I don't know why, and we saw him wander through cities and towns, spreading his teaching, surrounded by so many people, given so many gifts, and acclaimed for such great piety, that I don't ever remember anyone equally honoured. ${ }^{45}$
\end{abstract}

The focus on Peter's uncertain origins and location (indicative of a gyrovague), and the condemnation of his followers for introducing novelty, are likely allusions to the Rule of St. Benedict. An audience that lived by the rule would note such offences along with the pointed description of Peter's appearance, actions, and assumed holiness.

Whatever he did or said seemed like something almost divine. Even the hairs of his mule were torn out as though they were relics, which we report not as truth, but as a novelty loved by the common people. Outdoors he wore a woolen tunic, which reached to his ankles, and above it a hood; he wore a cloak to cover his upper body, and a bit of his arms, but his feet were bare. He drank wine and ate fish, but he scarcely ever ate bread. This man, partly because of his reputation, partly because of his preaching, had assembled a very large army, and decided to set out through the land of the Hungarians. ${ }^{46}$ 
The earlier statement, 'within our own borders,' therefore is an ironic nod that positions Hungary as the location of Peter's downfall.

Hungary in Dei Gesta Per Francos is presented as a bounteous land in which Peter's followers run amok and fail with their enterprise.

\begin{abstract}
The restless common people discovered that this area produced unusually abundant food, and they went wild with excess in response to the gentleness of the inhabitants. When they saw the grain that had been piled up for several years, as is the custom in that land, like towers in the fields, which we are accustomed to call "metas" in every-day language, and although supplies of various meats and other foods were abundant in this land, not content with the natives' decency, in a kind of remarkable madness, these intruders began to crush them. ${ }^{47}$
\end{abstract}

While the terminology and description of granaries may provide glimpses into the structure of late eleventh century Hungarian society, the details are included to criticise the misdirected followers of a gyrovage. Likewise, the Hungarians are depicted as devout Christians to stress the violence of the visitors who, like those in Bernold's Chronicon, commit crimes that go against the natural order.

While the Hungarians, as Christians to Christians, had generously offered everything for sale, our men wilfully and wantonly ignored their hospitality and generosity, arbitrarily waging war against them, assuming that they would not resist, but would remain entirely peaceful. In an accursed rage they burned the public granaries we spoke of, raped virgins, dishonored many marriage beds by carrying off many women, and tore out or burned the beards of their hosts. None of them now thought of buying what he needed, but instead each man strove for what he could get by theft and murder, boasting with amazing impudence that he would easily do the same against the Turks. ${ }^{48}$

Pointedly, Peter's followers are depicted behaving like the Muslims they had intended to fight; ${ }^{49}$ the ironic, knowing tone of the narration implies such a combat would not occur. Their engagement against fellow Christians, presented as inevitable, becomes and exemplum delivered with derision.

On their way they came to a castle that they could not avoid passing through. It was sited so that the path allowed no divergence to the right or left. With their usual insolence they moved to besiege it, but when they had almost captured it, suddenly, for a reason that is no concern of mine, they were overwhelmed; some died by sword, others were drowned in the river, others, without any money, in abject poverty, deeply ashamed, returned to France. And because this place was called Moisson, and when they returned they said that they had been as far as Moisson, they were greeted with great laughter everywhere. ${ }^{50}$ 
The coincidental bilingual homonym of the city Moson (Wieselburg), close to the western border of Hungary, and the French word for 'harvest' is used to ridicule Peter and his followers. Hungary provides the monastic author with a punchline at the expense of those deemed misguided.

Like Robert, Guibert used Hungary to stress the difference between Peter and Godfrey. The narrative, after stressing how 'Peter's group in no way helped the others,' returns 'to the men we have passed over, who followed the same path that Peter did, but in a far more restrained and fortunate way. ${ }^{51}$ To deliberately contrast Peter's itinerancy and vague origins, the lineage and nobility of the leaders is emphasised.

Duke Godfrey, the son of Count Eustace of Boulogne, had two brothers: Baldwin, who ruled Edessa, and succeeded his brother as King of Jerusalem, and who still rules there; and Eustace, who rules in the country he inherited from his father. ${ }^{52}$

Praising Godfrey's mother for her 'profound religious belief,' Guibert announces her son had previously informed her he wished to go to Jerusalem not simply (like a pilgrim) like others 'but forcefully, with a large army, if he could raise one. ${ }^{53}$ This inclusion turns Godfrey into a key figure in the enterprise, and presents the eventual success of the family in the Holy Land as divinely inspired and proof of the qualities of the social order. In contrast to Peter's troops,

With the splendid knightly ceremony and spectacle, the band of powerful young men entered the land of the Hungarians, in possession of what Peter was unable to obtain: control over his army. ${ }^{54}$

The contrasting experience of the two armies is presented by Guibert as an explanation one met defeat while the others achieved victory.

The manner of criticism, present in Bernold of Blaisen's Chronicon, that read defeat as divine punishment for sin, was a familiar feature of monastic literature. Guibert of Nogent's Gesta Dei Per Francos, expanding like his fellow Benedictine Robert the Monk the anonymous Gesta Francorum, incorporated such motifs in his depiction of the violence in Hungary to emphasise the differences between the Peter and Godfrey, and, like his fellow Benedictine, to view in contemporary history proof of the Benedictine Rule. The events in Hungary, presented by Guibert as an exemplum of crusading as a whole, reveals the confines and perspectives of a monastery. 


\section{Additional details, different perspective: Albert of Aachen's Historia Ierosolimitana}

Albert of Aachen's Historia Ierosolimitana has long been used by historians to fill in details of the failed attempts through Hungary lacking from the versions discussed earlier, often with little thought to his original intention. In the first book of his Historia, Albert presents the difficult journeys of Walter Sansavoir and Peter the Hermit, and the failed attempts of Gottschalk and Folkmar; in the second, the success of Godfrey of Bouillon; in the fourth, a reference to the events in Hungary provides a shorter interpretation of the occurrence. Owing to the size of the Historia, the account will be dealt with more succinctly than the previous versions.

After recording, contrary to other accounts, Peter as the instigator of the whole enterprise, Albert presents Walter, 'an outstanding warrior' entering 'the kingdom of Hungary with a great fellowship of Frankish footsoldiers and only eight knights who were starting on the journey to Jerusalem in response to the urging of the said Peter the Hermit. ${ }^{\prime 5}$ At the point Albert introduces the sympathetic ruler of Hungary, Coloman, 'the very Christian king of the Hungarians,' the important issue of granting the right to travel and licences for food is first introduced. ${ }^{56} \mathrm{Af}$ ter being provided with such grants, problems occur when Walter's forces reach 'Maleville' (lit. 'bad city,' likely Zemun) on Hungary's eastern border: sixteen men, attempting to buy arms after the rest had crossed the river Morava, are robbed by 'certain Hungarians with evil minds.' ${ }^{27}$ This event has possibly been shaped into an exemplum - either by Albert or his source - as is fittingly parallels a later even when a group, following unsuccessful dealings with Bulgar officials, separated from the rest of the army are burnt alive in a chapel. ${ }^{58}$ The two events stress the need for diplomacy and unity.

Albert presents sympathetically the same elements occurring to Peter the Hermit's contingent. ${ }^{59}$ His forces, assembled from numerous kingdoms, pitch their tents 'in front of the gates of Sopron' prior to negotiating transport with the Hungarian monarch. While reiterating the kindness of Coloman, the narration includes the condition that the travellers are permitted if they do not plunder, and procure goods 'without brawling and dispute': ${ }^{60}$ a warning of things to come. They travel peacefully - tellingly - 'without disturbance as far as' Zemun. ${ }^{61}$ When the audience of Albert's text hears that a rumour has spread among Peter's group as they reach the border that Guz, a count of Zemun and a Hungarian noble, has plotted with Duke Nichita, prince of the Bulgars and ruler of Belgrade, violence is expected. The shadowy Nichita, subject to scholarly debate as to his identity and role, ${ }^{62}$ has a clear role in the Historia: troubled by the rumour Peter misinterprets the earthly objects (the goods of his robbed predecessors hung on the ramparts) at the expense of the divine purpose (Jerusalem), and misdirects his 
followers into battle. Unlike the French Benedictines who mock, Albert praises: employing standard motifs of fighting and panegyrics, the Historia also emphasises via the losses, '[a]bout four thousand Hungarians [...] as few as a hundred of the pilgrims,' divine support for Peter's followers. ${ }^{63}$ Support however is fleeting: digressing from their goal, loitering at Zemun, a messenger (like Nichita, unverifiable: 'from a town of people unknown to the Franks') spurs them onwards by stating Coloman seeks revenge. ${ }^{64}$ A difficult crossing of the river Sava while under attack provides another exemplum: men from different nations, obeying a 'sworn promise of obedience,' rescue their Frankish brother and reiterate the importance of unity and a shared aim. ${ }^{65}$

The third force, led by Gottschalk, is presented differently. A German priest, inspired by Peter, led 'over fifteen thousand' with 'as many knights as common foot soldiers,' brought 'with honour' to the gates of Moson, are granted licences to trade 'lest a dispute arise from such a large army. ${ }^{\prime 66}$ Having forewarned his audience of the outcome, while narrating the idleness of Gottschalk's forces Albert both praises some of the group ('bold race') while condemning them ('foolishly drank too much'), possibly to placate while chiding veterans who returned. ${ }^{67}$ Noting they 'committed several crimes, all of which we cannot report, like a people foolish in their boorish habits, unruly and wild' - but not omitting to mention a stake driven through a young Hungarian's genitals - the Historia notes the Hungarian monarch desired 'the whole of Hungary to stir into battle in vengeance and not one of the pilgrims was to be spared because they had carried out this vile deed.' ${ }^{68}$ Perhaps to continue the previous image of Coloman and Hungary as devoutly Christian, the monarch is not named and the confrontation is located at a St. Martin's oratory in the center of Belgrade (not the Benedictine abbey at Pannonhalma, dedicated to the Pannonian St. Martin). ${ }^{69}$ There, Gottschalk's army acts in 'good faith,' believing the promise they would find favour by surrendering their arms and money, and are promptly slaughtered by the Hungarians ('professed Christians'). ${ }^{70} \mathrm{~A}$ modern view, that 'only a cohesive group would actually have surrendered this way, ${ }^{\prime 71}$ does not match the previous description of Gottschalk's army as unruly. The muddling of details, emphasising saintliness, doubting the Christian faith of the Hungarians (while not slandering Coloman by using his name), and labelling the massacre by a Christian army a martyrdom reveals authorial intention. In doing this, the Historia presents the followers of good faith, while reproaching them for forfeiting their funds that would have financed their journey to Jerusalem.

The lessons of the previous three attempts are repeated in the presentation of the final force. In contrast to the earlier forces, that are led by a leader that the text names, the final unsuccessful group is presented as a leaderless mob. Sexual misbehavior, made possible by such an enterprise, is condemned by Albert in a manner akin to Bernold of Blaisen (albeit without the complaint of monks dressed 
in normal clothes - likely due to Albert's own expressed desire to participate), before a 'vacillating statement' of the author's attitude towards the pogroms carried out by such armies in Central Europe. ${ }^{72}$ This seemingly-equivocal statement by Albert is likely a rhetorical ploy to focus his audience on the opportunism the 'intolerabilis' men and women, including Count Emicho, who 'continued the journey to Jerusalem with a large amount of booty, going in the direction of the kingdom of Hungary. ${ }^{73}$ With passage through Mosony prevented by Coloman having closed the bridge and gate of the fortress, the narrative of the Historia presents Emicho's forces besieging the city as inevitable. As with the depiction of Gottschalk's forces, Albert's presentation vacillates: on one hand noting the brave Hungarian defenders, on the other, presenting the killing of a notable Hungarian figure in a manner reminiscent of a chanson de geste. ${ }^{74}$ The Historia presents victory as being so close that Coloman's forces were preparing to flee to Russia: a detail Emicho's forces were unlikely to have known (or subsequently discovered and passed on to Albert). Once again, though the small engagements are successful, such deeds are a distraction from Jerusalem. With Emicho fleeing as his army 'scattered and alarmed like sheep when attacked by wolves, ${ }^{75}$ defeat is snatched from the jaws of victory because the leaders are unable to regard the signs and follow them. Misdirection, and bad behavior, led Albert to conclude 'the hand of God is believed to have been against the pilgrims. ${ }^{76}$ After this account, Albert reiterates these lessons with a pointed exemplum and a rhetorical question: recording 'another abominable wickedness in this gathering of people on foot,' that some followed a goose and a she-goat believed to be inspired by the Holy Ghost, the Historia noted 'the rod of his majesty' was 'swift and purifying. ${ }^{77}$ With its accounts of the attempted journeys across the land, the Historia Ierosolimitana positions Hungary as God's divine baton.

In deliberate contrast, the second book of the Historia presents the successful journey of Godfrey of Bouillon's forces as an exemplum how it should be done and a chastisement of what came before. Recounting how Godfrey's contingent stayed near Tulln (on the border with Hungary) to gather information and begin diplomacy, Albert includes a series of documents related to Hungary. Though regarded by scholars as 'fictum' (meaning literary and non-historical), ${ }^{78}$ this material is significant in the reception of the events. Coloman replies to Godfrey's query - why a Christian king destroyed a Christian army, ${ }^{79}$ a question that would have lingered among those that survived - with a retelling of the events of the first book of the Historia, a mouthpiece for Albert to reiterate to his audience why some armies were successful and others not. With repeated mentions of good will, trust, and good faith, Godfrey and Coloman are presented exemplary; their resolution, concerning how a large foreign force should peacefully travel through a country, reached after diplomacy at Sopron, stresses how Coloman is a Christian monarch and how different Godfrey was to his predecessors. The duke, de- 
picted as concerned for future crusaders (an 'army of pilgrims' - the terminology was in development), appears in the Historia as an emerging Christian ruler. The use of his brother, Baldwin, as a hostage (with Godfrey offering to swap places and let his brother lead 'God's army' when his sibling protests) presents the future ruler of Jerusalem advantageously. ${ }^{80}$ With the success of Godfrey's journey across the country presented as evidence of his later success, Hungary - and its ruler - are positioned in Albert's Historia as the decider of who and what constitutes a crusader.

This use of Hungary, explaining to those who fled from the earlier failed why they had failed, shows the Historia acting as a corrective to criticism of the crusade that emerged from the violence. A rallying speech in book four by a Lombard cleric made at Antioch in 1098 has been seen as evidence that different views existed concerning the motivation of the crusaders. ${ }^{81}$ The speech presents a dialogue between a priest and a man dressed as a pilgrim who had asked where the enterprise began. The priest answers that 'different people think different things about this journey,' and that those who went 'for reasons of frivolity' caused 'so many pilgrims [to] have met obstacles in the kingdom of Hungary and in other kingdoms.' 82 The man responds that the origin was not frivolous but divinely ordained, and he states that those killed on the journey who 'abstained from avarice, theft, adultery, and fornication' 83 will be crowned as martyrs in heaven, and reveals himself as St. Ambrose, the noted bishop of Milan. The mention of Hungary, and only Hungary by name, is significant: why, after all the army had endured, would reference be made to such an event? This 'evocation after the fact of an event that took earlier than the point in the story where we are' ${ }^{84}$ is Albert using the Lombard cleric to rally his own audience to the enterprise. Associating the fledging crusaders with pilgrims (and St. Ambrose), identifying the slain as martyrs, Albert repeats his earlier interpretative framework of the attempted journeys through Hungary to answer to an audience likely familiar with criticisms from those returning: though misbehavior was divinely punished, those associated with pilgrims (and St. Ambrose) died not in vain in Hungary but as martyrs. This position taken by Albert may also allude to a contemporary event: the uneventful passage of Lombards (and the then-incumbent bishop of Milan) during the Crusade of 1101 through Hungary, an occurrence that likely saw the same questions about the early setbacks in Hungary. ${ }^{85}$

\section{Schooling the Monastics: the anonymous Charleville poet}

The additions by an anonymous hand in a single manuscript of Gilo of Paris's Historia Via Hierosolitana are the exception that proves the rule. The expansion of Gilo's Historia, itself a metrical rewrite of the Gesta Francorum, included a 
new opening depicting the events in Hungary omitted by Gilo and his source. Likely writing for a schoolroom rather than a monastery, the additions by the 'Charleville Poet' show how the Benedictine interpretation of the events in Hungary became such an accepted feature of the narrative of the First Crusade that its absence required it to be inserted. ${ }^{86}$

The additions made by the anonymous poet are didactic rather than details. The armies prior to Godfrey are presented as a directionless single force, with Peter and Walter criticized for lacking leadership. ${ }^{87}$ The arrogance of the army, believing themselves worthy of being treated as apostles, believing too quickly they would receive supplies because they were heralds of the gospel, is used by the anonymous poet to explain how the religious adherents, lacking provisions but with crosses sewn on their clothing, resorted to theft in Hungary - entering like citizens, but rapidly becoming hostile..$^{88}$

In presentation and judgment, the Charleville Poet differs from the Benedictines. Depicting the violence as the Hungarians respond to the wild behavior of Peter's followers, classical allusions appear where biblical allusions and divine judgment would be stressed. ${ }^{89}$ Sympathy is shown for those caught in the turmoil, and a less scriptural view of religion appears: the burning of a chapel containing relics (and some followers of Walter) - which Albert places in Bulgaria - is placed by the poet in Hungary, who also asserts the site became a place of miracles and, subsequently, a place of pilgrimage with healing properties. ${ }^{90} \mathrm{~A}$ failed siege, also misplaced geographically and chronologically, is presented in contrast to the scornful Benedictine authors sympathetically and without doctrinal hostility. ${ }^{91}$

Though sympathetic, the additions to Gilo's Historia stress a clear didactic message. The Charleville Poet divides the journey through Hungary into two the first that fails, the second successful - a division emphasized by separating their accounts into different books of the poem, and by the Poet claiming Peter's forces 'almost caused the journey to the Holy Sepulcher to be abandoned,' presenting their behavior as a wound requiring healing. ${ }^{92}$ Godfrey is presented by the poet as the cure, with the events in Hungary emphasizing his abilities in contrast to his predecessors. When confronted after crossing the Danube by fleeing stragglers urging them to turn back, Godfrey rallies his susceptible followers with a stirring speech. ${ }^{93}$ The exhortation is used by the Charleville Poet to stress an interpretation of the events. Asserting that those who had set out with the right intentions, offered prayers in holy places (like Godfrey), and, following Matthew $5: 8$, 'did not seek temples of precious treasures, but rather loved holy, pure, and blameless hearts, ${ }^{, 94}$ will succeed, the Charleville Poet, via Godfrey, optimistically inverts the Benedictine assertion that misbehavior will result in defeat. The oration, full of rhetorical flourish incorporating Biblical and classical allusions, presents Hungary as the threshing-floor that sifts out the chaff in the breeze that 
blows and Godfrey as committed to the militaristic and religious enterprise and capable of succeeding where the earlier group had failed. The passage, showy with erudition, is likely designed for students to grapple with an argument and figure rhetoric via their local hero Godfrey.

In addition to the orations, the message is also stressed in the narrative. Though greater length is given to Godfrey's imagined oration, the brief account of diplomatic dealings with the Hungarians - dealt with at length in Albert's Historia - similarly reiterates the Charleville Poet's didactic method. Godfrey displays exemplary behavior, handing his brother over as a hostage, while the Hungarians, following careful scrutinizing of the details, proceed to welcome the army with gifts and celebrations. ${ }^{95}$ Stressing the difference between Peter and Godfrey, the Hungarians likewise behave differently: having previously been violent and destroyed relics, they greet Godfrey's forces with a religious procession with their (unnamed) king kissing religious objects. This becomes the moment the Charleville Poet chooses to record that this land is the birthplace of St. Martin of Tours. ${ }^{96}$ The anonymous expander of Gilo's Historia used the events in Hungary to explain the events of the crusade as a whole, concluding the Hungarian section:

\footnotetext{
They went on from here and progressed on a long march through the areas where the first to go had endured the aforementioned dangers. They learned the value of moderation and good counsel, and the harm caused by rashness and wild frenzy, for those who had been hostile to their predecessors, bringing about their tragic downfall, were now their humble and obedient servants. ${ }^{97}$
}

Hungary illuminates the crusaders, and the crusaders illuminate Hungary.

Less doctrinal than the French Benedictine versions, less detailed than Albert's Historia, the account inserted by the anonymous Charleville Poet presents a sympathetic variant to the monastic rewriters. The claim that the success of such an enterprise is dependent on the actions of armies and their leaders likewise presents Hungary as a divine threshing-floor to explain the early defeats and, subsequently, the values of the enterprise as a whole.

\section{Conclusion: Seeing Historical Text seeing the Historical Event}

By viewing the sources as unique texts, a nuanced understanding of how the violence was interpreted by a variety of authors is reached. Literary techniques such as exegesis, exempla, allusion, and affabulation, and the inclusion of considered motifs such as the attributes of gyrovagues, defeat in battle following sexual misbehavior, and Hungary as a threshing-floors, reveal the cultural and religious contexts of these authors and their intended audiences. Whether the intention was 
to reassert Benedictine values and place onto the event a religious interpretation or to inspire schoolboys with a local hero, the choices made by the individual authors provide evidence of the historical perceptions of the events in Hungary. Rather than creating a piecemeal narrative by cutting and pasting these sources together, such an approach reveals the deliberate casting of a semi-Christianized territory on the periphery of the Latin West into a microcosm, and exemplum, of the emerging crusade movement. ${ }^{98}$

\section{Acknowledgements}

This revision of "The Threshing-Floor Sifts Out the Chaff in the Breeze that Blows": Comprehending the Role of Hungary in the First Crusade,' read at conferences at CEU and UCL SSEES, was supported by a Tempus Public Foundation Fellowship.

\section{Notes}

1 7/6 Aaly Tokombaev Street, Bishkek, Kyrgyz Republic, 7200600 jamesplumtree@ gmail.com

2 The following abbreviations are used: $A A$ - Albert of Aachen, Historia Ierosolimitana: History of the Journey to Jerusalem, ed. and tr. Susan Edgington (Oxford: Clarendon Press, 2007); GF - Gesta Francorum et aliorum Hierosolimitanorum: The Deeds of the Franks and the other Persons to Jerusalem, ed. and tr. Rosalind Hill (Oxford: Clarendon Press, 1979); GN-The Deeds of God through the Franks: A Translation of Guibert of Nogent's Gesta Dei Per Francos, tr. Robert Levine (Woodbridge: Boydell Press, 1997); HVH - The Historia vie Hierosolimitane of Gilo of Paris and a second anonymous author, ed. and tr. C. W. Grocock and J. E. Siberry (Oxford: Clarendon Press, 1997); RM-Robert the Monk's History of the First Crusade: Historia Iherosolimitana, tr. Carol Sweetenham (Aldershot: Ashgate, 2006); for sources unavailable in bilingual editions, RHC Occ-Recueil des Historiens des Croisades: Historiens occidentaux, 5 vols (Paris: Imprimerie Impériale, 1844-95). Absent from this study is the work of Frutolf and his continuators; it is hoped this will be addressed in a separate study.

3 For instance the shared reliance on Albert in Steven Runciman, A History of the Crusades (Cambridge: Cambridge University Press, 1951-54), 52-55 and 66-74, and Christopher Tyerman, God's War: A New History of the Crusades (Cambridge, MA: Harvard University Press, 2006), 94-103 and 109.

4 Catalogus fontium historiae Hungaricae, ed. Ferenc Albin Gombos, 4 vols (Budapest: Szent István Akadémia, 1937-43) is the Hungarian example of this method; the recent reprinting by Nap Kiadó (2005-11), testifies to its usefulness. 'Szemelvények a korai keresztes hadjáratok történetéhez', a compilation of extracts mentioning Hungary translated into Hungarian, in Magyarország és a Keresztes Háborúk: Lovagrendek 
és Emlékeik, ed. József Laszlovszky, Judit Majorossy, and József Zsengellér (Máriabesnyő-Gödöllö: Attraktor, 2006), 283-311, shares a similar purpose. Zsolt Hunyadi, 'Hungary and the Second Crusade', Chronica 9-10 (2009-2010), 55-65, has recently clarified the 'Sweeney Thesis' proposed in James Ross Sweeney, 'Hungary in the Crusades, 1169-1218', International History Review 3 (1981): 467-81.

5 Writing the Early Crusades: Text, Transmission and Memory, ed. Marcus Bull and Damien Kempf (Woodbridge: Boydell Press, 2014); Rodney M. Thomson, 'William as Historian of Crusade', in William of Malmesbury (Woodbridge: Boydell Press, 2003), 178-88; Daniel Roach, 'Orderic Vitalis and the First Crusade', Journal of Medieval History 42 (2016): 177-201.

6 'Papsturkunden in Florenz', ed. W. Wiederhold, Nachrichten von der Gesellschaft der Wissenschaften zu Göttingen (1901): 306-25 (here 313), tr. Jonathan Riley-Smith, The First Crusade and the idea of crusading (1983; London: Continuum, 2003), 26.

7 Katherine Allen Smith, War and the Making of Monastic Culture (Woodbridge: Boydell Press, 2011), 39-70.

8 Nora Berend, At the Gate of Christendom: Jews, Muslims, and 'Pagans' in Medieval Hungary, c. 1000-c. 1300 (Cambridge: Cambridge University Press, 2001); Nora Berend, 'Hungary, "the Gate of Christendom", in Medieval Frontiers: Concepts and Practices, ed. David Abulafia and Nora Berend (Burlington, VT: Ashgate, 2002), 195-215; Nora Berend, József Laszlovsky, and Béla Zsolt Szakács, 'The Kingdom of Hungary', in Christianization and the Rise of Christian Monarchy: Scandinavia, Central Europe and Rus c. 900-1200, ed. Nora Berend (Cambridge: Cambridge University Press, 2007), 319-68; Gábor Klaniczay, Holy Rulers and Blessed Princesses: Dynastic Cults in Medieval Europe, tr. Éva Pálmai (Cambridge: Cambridge University Press, 2002), 123-34.

9 Rodulfus Glaber Opera, ed. John France, Neithard Bulst, and Paul Reynolds (Oxford: Clarendon Press, 2002), 38-39, 96-97; Attila Györkös, 'La relation de Raoul Glaber sur les premières décennies de l'Etat hongrois', in The First Millennium of Hungary in Europe, ed. Klára Papp and János Barta (Debrecen: Debrecen University Press, 2002), 120-26. For earlier pilgrimages taking this route: Richard Landes, Relics, Apocalypse, and the Deceits of History: Ademar of Chabannes, 989-1034 (Cambridge, MA: Harvard University Press, 1995), 154-58; Einar Joranson, 'The Great German Pilgrimage of 1064-1065', in The Crusades and Other Historical Essays Presented to Dana C. Munro by his Former Students, ed. Louis J. Paetow (New York: Crofts, 1928), 3-56

10 Katalin Szende, 'Traders, 'Court Jews', Town Jews: Changing Roles of Hungary's Jewish Population in the Light of Royal Policy between the Eleventh and Fourteenth Centuries' in Intricate Interfaith Networks: Quotidian Jewish-Christian Contacts in the Middle Ages, ed. Ephraim Shoham-Steiner and Gerhard Jaritz (Turnhout: Brepols, 2016), 93-115 (here 94-97); Enikő Spekner, 'Buda before Buda: Óbuda and Pest as Early Centers', in Medieval Buda in Context, ed. Balázs Nagy, Martyn Rady, Katalin Szende, and András Vadas (Leiden: Brill, 2016), 71-91 (here 82).

11 Walter Porges, 'The Clergy, the Poor, and the Non-Combatants on the First Crusade', Speculum 21 (1946): 1-23; Conor Kostick, The Social Structure of the First Crusade (Leiden: Brill, 2008). Regarding Peter's role and capabilities, see E. O. Blake and C. 
Morris, 'A Hermit Goes to War: Peter and the Origins of the First Crusade', Studies in Church History 21 (1984): 79-107; Colin Morris, 'Peter the Hermit and the Chroniclers', in The First Crusade: Origins and Impact, ed. Jonathan Phillips (Manchester: Manchester University Press, 1997), 21-34; Jay Rubenstein, 'How, or How Much, to Reevaluate Peter the Hermit', in The Medieval Crusade, ed. Susan J. Ridyard (Woodbridge: Boydell Press, 2004), 53-69; Charles R. Glasheen, 'Provisioning Peter the Hermit: from Cologne to Constantinople, 1096', in Logistics of Warfare in the Age of the Crusades, ed. John Pryor (Aldershot: Ashgate, 2006), 119-129.

12 Alan Murray, 'The army of Godfrey of Bouillon, 1096-1099: structure and dynamics of a contingent on the First Crusade', Revue belge de philology et d'histoire 70 (1992): 301-29.

13 Susan Edgington, 'The First Crusade: Reviewing the Evidence', in The First Crusade, ed. Phillips, 55-77; Jonathan Riley-Smith, 'Pilgrims and Crusaders in Western Latin Sources', Proceedings of the British Academy 132 (2007): 5-21.

14 Die Chroniken Bertholds von Reichenau und Bernolds von Konstanz 1054-1100, ed. Ian S. Robinson (Hannover: Hahnsche Buchhandlung, 2003), 527-29.

15 C. J. Tyerman, 'Were There Any Crusades in the Twelfth Century?', English Historical Review 110 (1995): 554-77.

16 James A. Brundage, 'Prostitution, Miscegenation and Sexual Purity in the First Crusade', in Crusade and Settlement: Papers read at the first conference of the Society for the Study of the Crusades and the Latin East presented to R. C. Smail, ed. Peter W. Edbury (Cardiff: University College Cardiff Press, 1985), 57-65; Léan Ní Chléirigh, 'Nova Peregrinatio: The First Crusade as a Pilgrimage in Contemporary Latin Narratives', in Writing the Early Crusades, ed. Bull and Kempf, 63-74.

17 Colin Morris, 'The Gesta Francorum as Narrative History', Reading Medieval Studies 19 (1993): 55-71; Rubenstein, 'What is the Gesta Francorum'; Conor Kostick, 'A further discussion on the authorship of the Gesta Francorum', Reading Medieval Studies 35 (2009): 1-14; Kenneth Baxter Wolf, 'Crusade and narrative: Bohemond and the Gesta Francorum', Journal of Medieval History 17 (1991): 207-16.

18 For the relationship between GF and Raymond of Aguilers' Historia Francorum qui ceperunt Iherusalem, Fulcher of Chartres' Historia Hierosolymitana, and Peter Tubode's Historia de Hierosolymitano itinere: John France, 'The Use of the Anonymous Gesta Francorum in the Early Twelfth-Century Sources for the First Crusade', in From Clermont to Jerusalem: The Crusaders and Crusader Societies, 1095-1500, ed. A. V. Murray (Turnhout: Brepols, 1998), 29-42, and 'The Anonymous Gesta Francorum and the Historia Francorum qui ceperunt Iherusalem of Raymond of Aguilers and the Historia de Hierosolymitano itinere of Peter Tudebode: An Analysis of the Textual Relationship between Primary Sources for the First Crusade', in The Crusades and their Sources: Essays Presented to Bernard Hamilon, ed. John France and William G. Zajac (Aldershot: Ashgate, 1998), 39-69; Jay Rubenstein, 'What is the Gesta Francorum, and who was Peter Tudebode?', Revue Mabillon 16 (2005), 179-204.

19 Marcus Bull, 'The Western narratives of the First Crusade', in Christian-Muslim Relations. A Bibliographical History, vol. 3, 1050-1200, ed. David Thomas and Alex Mallett (Leiden: Brill, 2011), 15-25 (here 19). 
20 AA, 2-3; the name 'Albert', xxiii.

21 Riley-Smith, 'Pilgrims and Crusaders', 15.

$22 A A$, xxv.

23 Reappraisal of $A A$ has been greatly aided by the work of his editor, Edgington.

24 Riley-Smith, First Crusade and the idea of crusading, 135-152; for criticism of this term, see Jay Rubenstein, 'Miracles and the Crusading Mind: Monastic Meditations on Jerusalem's Conquest', in Prayer and Though in Monastic Tradition: Essays in Honour of Benedictia Ward SLG, ed. Santha Bhattacharji, Rowan Williams, and Dominic Mattos (London: Bloomsbury, 2014), 197-210.

25 A. C. Krey, 'A neglected passage in the Gesta and its bearing on the literature of the First Crusade', in The Crusades, and other historical essays: presented to Dana C. Munro by his former students, ed. Louis J. Paetow (New York: F. S. Crofts, 1928), 57-76; Nicholas L. Paul, 'A Warlord's Wisdom: Literacy and Propaganda at the Time of the First Crusade', Speculum 85 (2010): 534-66.

26 Elizabeth Lapina, “Nec signis nec testis creditor...": The problem of eyewitnesses in the chronicles of the First Crusade', Viator 38 (2007): 117-39.

27 Smith, War and the Making of Medieval Monastic Culture, 3.

28 Brian Stock, The Implications of Literacy: Written Language and Models of Interpretation in the Eleventh and Twelfth Centuries (Princeton: Princeton University Press, 1983), 90-91.

29 Katherine Allen Smith, 'Glossing the Holy War: Exegetical Constructions of the First Crusade, c.1099-c.1146', Studies in Medieval Renaissance History, 3rd series, 10 (2013), 1-39.

30 Dating, $A A$, xxv; regarding songs, Susan Edgington, 'Albert of Aachen and the chanson de geste, in The Crusades and their Sources: Essays Presented to Bernard Hamilton, ed. John France and William G. Zajac (Aldershot: Ashgate, 1998), 23-57; regarding Albert's views throughout the work, see $A A$, xxix.

31 Marcus Bull, 'Robert the Monk and his Source(s)', in Writing the Early Crusades, ed. Bull and Kempf, 127-39; regarding dating of Charleville-Mézières Bibliothèque Municipale MS 97, $H V H$, xxiv; for other texts in the manuscript indicative of schoolroom use, xxiii.

$32 G F, 2$ : 'Fecerunt denique Galli tres partes. Vna pars Francorum in Hungariae intrauit regionem, scilicet Petrus Heremita, et dux Godefridus, et Balduinus frater eius, et Balduinus comes de Monte. Isti potentissimi milites et alii plures quos ignoro uenerunt per uiam quam iamdudum Karolus Magnus mirificus rex Franciae aptari fecit usque Constantinopolim.' Other 'eyewitness' accounts omit the passage entirely.

33 GF, 2 (Peter), 4 ('Guualterius Sinehabere'), 6 (Godfrey); Hugh, I, Count of Vermandois preceded Godfrey in reaching Constantinople

34 RHC Occ III, 721-23; RM, 75-77; aforementioned Constantinople error: $R H C$ Occ III, $743 ; R M, 94$.

$35 R M, 83$; RHC Occ III, 731-2: 'Erat in illis diebus quidam, qui heremita exstiterat, nomine Petrus, qui apud illos qui terrena sapiunt magni aestimabatur, et super ipsos praesules et abbates apice religionis efferebatur, eo quod nec pane nec carne vesceba- 
tur, sed tamen vino aliisque cibis omnibus fruebatur et famam abstinentiae in deliciis quaerebat.'

36 The Rule of Saint Benedict, ed. and tr. Bruce L. Venarde (Cambridge, MA: Harvard University Press, 2011), 16-19: 'Quartum vero genus est monachorum quod nominatur gyrovagum, qui tota vita sua per diversas provintias ternis aut quaternis diebus per diversorum cellas hospitantur, semper vagi et numquam stabiles et propriis voluntatibus et gulae inlecebris servientes et per omnia deteriores sarabaitis. De quorum omnium horum miserrima conversatione melius est silere quam loqui.'

37 RM, 84, emended; RHC Occ III, 731-2: 'Hic vultu elegans, statura procerus, dulcis eloquio, moribus egregius, et in tantum militibus lenis, ut magis in se monachum quam militem figuraret. Hic tamen quum hostem sentiebat adesse et imminere praelium, tunc audaci mente concipiebat animum, et, quasi leo frendens, ad nullius pavebat occursum. Et quae lorica vel clypeus sustinere poterat impetum mucronis illius? Hic, cum fratribus suis Eustachio et Balduino et magna manu militum peditumque, per Hungariam iter arripuit, per viam scilicet quam Karolus Magnus, incomparabilis rex Francorum, olim suo exercitui fieri usque Constantinopolim praecepit.'

38 Tr. Kostick, Social Structure, 283; Chroniken, 528: 'Nimium tamen simpliciter innumerabilis multitudo popularium illud iter arripuerunt, qui nullomodo se ad tale periculum praeparare noverunt vel potuerunt.'

39 Porges, 'The Clergy, the Poor'; Kostick, Social Structure.

40 Kostick, Social Structure, 283; Chroniken, 528-29: 'Non erat autem mirum, quod propositum iter ad Ierosolimam explere non potuerunt, quia non tali humilitate et devotione, ut deberent, illud iter adorsi sunt. Nam et plures apostatas in comitatu suo habuerunt, qui abiecto religionis habitu cum illis militare proposuerunt. Sed et innumerabiles feminas secum habere non timuerunt, que naturalem habitum in virilem nefarie mutaverunt, cum quibus fornicati sunt. In quo Deum mirabiliter sicut et Israheliticus populus quondam offenderunt. Unde post multos labores, pericula et mortes, tandem, cum Ungariam non permitterentur intrare, domum inacte cum magna tristicia ceperunt repedare.'

41 Elizabeth Siberry, Criticism of Crusading 1095-1274 (Oxford: Clarendon Press, 1985), 69-108.

42 Rom 10:2; GN, 47; RHC Occ IV, 142.

$43 G N, 47$; RHC Occ IV, 142: 'Principibus igitur, qui multis expensis, et magnis obsequentium ministeriis indigebant, sua morose ac dispensative tractantibus, tenue illud quidem substantia, sed numero frequentissimum, vulgus Petro cuidam Hermitae cohaesit; eique interim, dum adhuc res intra nos agitur, ac si magistro paruit.'

44 Colin Morris, 'Peter the Hermit and the Chroniclers', in The First Crusade: Origins and Impact, ed. Jonathan Phillips (Manchester: Manchester University Press, 1997), 21-34 (here 24).

45 GN, 47; RHC Occ IV, 142: 'Quem ex urbe, nisi fallor, Ambianensi ortum, in superiori nescio qua Galliarum parte solitariam sub habitu monachico vitam duxisse comperimus; inde digressum, qua nescio intentione, urbes et minicipia praedicationis obtentu circumire vidimus, tantis populorum multitudinibus vallari, tantis muneribus donari, tanto sanctitatis praeconio conclamari, ut neminem meminerim simili honore haberi.' 
46 GN, 47-48; RHC Occ IV, 142: 'Multa enim fuerat, ex his quae sibi dabantur, dilargitione erga pauperes liberalis; prostitutas mulieres non sine suo munere maritis honestans; in discordibus ubique paces et foedera, mira auctoritate, restituens. Quicquid agebat namque seu loquebatur, quasi quiddam subdivinum videbatur, praesertim quum etiam de ejus mulo pili pro reliquiis raperentur: quod nos non ad veritatem, sed vulgo referimus amanti novitatem. Lanea tunica ad purum, cucullo super, utrisque talaribus, byrro desuper utebatur, brachis minime, nudipes autem; vino alebatur ac pisce, pane vix aut nunquam. Is autem vir, partim opinione, partim suo monitu quum immanem conflasset exercitum, per Hungarorum terram delegit abire.'

47 GN, 48; RHC Occ IV, 142-43: 'Quorum regiones quum earum rerum quae ad alimentum pertinent opulentissimas, idem vulgus indocile repperisset, coeperunt luxuriis enormibus contra indigenarum mansuetudinem debacchari. Quum enim plurimorum annorum segetes triticeas, ut in ea terra moris est, in modum turrium per agros stabilitas cernerent, quas nos metas vulgariter vocare solemus; quum carnium diversarum aliorumque victualium, quorum illa feracissima tellus est, copiae suppeterent, non contenti humanitate eorum, mira dementia, ipsi alienigenae coeperunt turpiter conculcare gentiles'.

48 GN, 48; RHC Occ IV, 143: 'et quum idem, utpote Christiani Christianis, venalia cuncta gratanter ingererent, illi, libidinis impatientes, piae hospitalitatis ac beneficientiae immemores, bello gratis eos aggrediuntur: dum illos opinantur nihil ausuros contra, ac penitus futuros imbelles. Rabie igitur execranda, publicis quos diximus horreis per eos ingerebatur incendium; puellis eripiebatur violentia illata virginium; dehonestabantur connubia crebris raptibus feminarum; vellebant sive ustulabant suis barbas hospitibus. $\mathrm{Nec}$ jam de emendis usui necessariis quicpiam tractabatur, sed quisque eorum, prout poterat, rapinis et caedibus nitebatur: sic se acturos mira lascivia contra Turcos libere minabantur.'

49 Gesta Dei Per Francos included earlier a depiction of a rampaging Muslim horde from the spurious letter from the Greek Emperor to Robert, count of Flanders: RHC Occ 4, 131-32; GN, 36-37; for the letter, $R M, 215-22$; Einar Joranson, 'The Problem of the Spurious Letter of Emperor Alexius to the Count of Flanders', American Historical Review 55 (1950): 811-32.

$50 \mathrm{GN}, 48, \mathrm{RHC} O c c$ 4, 143: 'Castrum quoddam interea habuere pervium, cujus nullo modo poterant evitare transitum; is enim terrae situs est, ut in modum angiporti nequaquam ad dexteram vel sinistram pateat diverticulum. Ipsum solita insolentia obsidere aggressi sunt, sed quum prope capiendum esset, repente, non curo quo eventu, ita obruti sunt, ut pars gladiis occumberet, partem fluvialis unda submergeret, pars sine ullis stipendiis, immo turpi pauperie, magis autem pudore, in Franciam consumpta rediret. Et quare idem castrum Moissonem vocabant, et reversi ad suos ad Moissonem usque se fuisse dicebant magna omnium irrisione excepti sunt.'

51 GN, 52; RHC Occ 4, 146: 'Nunc itaque ad eos quos omiseramus, qui eadem, qua Petrus praecesserat, subsecuti sunt via, sed longe feliciori modestia, revertamur.'

52 GN, 52; RHC Occ 4, 146-47: 'Dux Godefridus, Eusthacii Boloniensium comitis filius, duos habuit fraters: Balduinum, qui Edisseriae urbi praefuit, et post ipsum fratrem rex effectus Iherosolimae, nunc usque regnat; et Eusthacium, qui paterno comitatui praest.' 
$53 G N, 52 ; R H C$ Occ 4, 147: 'Dicebat namque se desiderare proficisci Iherosolimam, et hoc non simpliciter, ut alii, sed cum violentia exercitus, si sibi copia suppeteret, magni. Cui, secundum divinum a qup imbuebatur instinctum, mirabilis super hoc postmodum opportunitas arrisit.'

54 GN, 52-53; RHC Occ 4, 147: 'Cum nobili igitur rerum equestrium pompa et spectabili fortissimorum juvenum frequentia, Hungarorum ingrediuntur terram, habentes tamen eam, quam Petrus tenere non valuit, erga suos milites disciplinam; et duobus ante.'

55 AA, 8-9: 'Walterus cognomento Senzauehor miles egregious, cum magna societate Francigenarum peditum, solummodo octo habens equites, ex admonitione predicti Petri Heremite in initio uie Ierusalem intrauit regnum Vngarie.'

$56 A A, 8-9$ : 'Vbi cognita et audita illius animi intentione, et causa assumpte uie, a domno Kalamanno rege Christianissimo Vngariorum benigne susceptus est, et pacifice concessus est sibi transitus per uniuersam terram regni sui, et emendi licentia. Hic itaque sine offensione et aliquo aduerso incursu, usque ad Belegrauam ciuitatem Bulgarorum profectus est, transiens Maleuillam, ubi terminantur fines regni Vngariorum.'

$57 A A, 10-11:$ 'Vngari uero quidam peruerse mentis'

$58 A A, 10-11$.

59 The biblical allusion, 'innumerable as the sand of the sea' (1 Sam 13:5; 2 Sam 17:11), attached to Peter's forces is ambivalent given it describes the Israelites that followed Absalom and the Philistines that threaten Paul.

$60 A A, 12-13:$ 'sine iurgio et lite'.

$61 A A, 12-13$ : 'sic sine turbine usque ad Maleuillam cum omni legione sua profectus est.'

$62 A A, 12-15$ renders 'duce, Nichita nomine, principe Bulgarorumet preside ciuitatis Belgrade' as 'duke' and 'prince of the Bulgars and ruler of the city of Belgrade'; Nicolae Iorga, Les Narrateurs de la Première Croisade (Paris: Gamber, 1928), 21: 'le commandant byzantine de Belgrade'; John France, Victory in the East: A Military History of the First Crusade (Cambridge: Cambridge University Press, 1996), 90 a Byzantine governor; Elena Koytcheva, 'Byzantine-Balkan and Western Titles in the Latin Sources of the First Crusades', Revue des Études sud-est Européennes 43 (2005): 123-132 (here 128-129) noted 'Duke' does not fit the Slavic equivalent 'knjaz' nor fits into Byzantine hierarchy; Günter Prinzing, 'Zu Odessos/Varna (im 6. Jh.), Belgrade (1096) und Braničevo (um 1163): Klärung dreier Fragen aus Epigraphik, Prosopographie und Sphragistik', Byzantinoslavica 56 (1995) 219-225 (220-224) argued the epithets - princeps and praeses - is an attempted translation of protoproedros, the 'first proedros', the highest dignitary; Alexandru Madgearu, Byzantine Military Organization on the Danube, $10^{\text {th }}-12^{\text {th }}$ Centuries (Leiden: Brill, 2013), 98-99, noted Nicheta is the namesake of Niketas Karykes, commander of the theme of Sirmium in 1071. The Hungarian Guz has received less scholarly attention.

63 AA, 16-17: 'Cecidererunt illic circiter quatuor milia Vngariorum; peregrinorum centum tantum preter uulneratos ibidem occisi sunt.'

64 AA, 16-17: 'Transactis abhinc sex diebus, nuncius quidam de uilla aduenarum Francorum Petro celeriter mittitur, qui hanc minarum certam legationem illi indicaret dicens: "Rex Vngarie collecto exercitu uniuersi regni sui in ultione suorum ad uos descensurus est, de quibus nec unum quidem certum est ab armis illius euadere. Nam dolor 
occisorum et lamenta regem et uniuersos parentes et amicos illorum commouerunt. Quapropter quantocius fluuium Maroam superantes, uiam uestram hinc maturate."”

$65 A A, 16-19$; note the mnemonic repetition of seven.

$66 A A, 44-45$ : 'supra quindecim contraxit milia [...]. Ad portam uero Meseburch, et eius presidium gratia regis Kalamanni uenientes, honorifice introducti sunt. Quibus etiam concessa est licentia emendi uite necessaria, et pax utrinque indicta ex precepto regis, ne qua seditio a tanto oriretur exercitu'.

$67 A A, 44-45:$ 'gens animosa et ceteri fatui modum potandi excederent'.

$68 A A, 46-47$ : 'Cetera plurima flagitia que omnia referre nequimus perpetrarunt, sicut gens rusticano more insula, indisciplinata et indomita. Iuuenem enim quendam Vngarum, ut aiunt qui presentes fuerunt, pro uilissima contentione palo per secreta nature transfixerunt in fori platea. [...]Hac rex infamia inquietatus, omnique domu illius turbata, precepit satellitibus suis se armare, et signo totam Vngariam in ultionem huius facinoris ceterarumque contrumeliarum commoueri, et nulli peregrinorum parcere, eo quod fedam rem perpetrassent.'

$69 A A, 46-47$ : 'et in campo Belegraue secus oratorium sancti Martini conglobate sunt'.

$70 A A, 46-49$.

71 France, Victory, 92.

72 Benjamin Z. Kedar, 'Crusade Historians and the Massacres of 1096', Jewish History 12 (1998): 11-31 (here 20).

$73 A A, 52-53$ : 'et omnis illa intolerabilis societas uirorum ac mulierum, uiam Ierusalem continuauerunt, tendentes uersus regnum Vngarie ubi transitus regis uia uniuersis peregrinis minime negari solebat'.

$74 A A$, 54-55: 'In hac conflictione Willelmus principem exercitus Vngarorum, et collateralem regis congressus, uirum illustrem et niueis crinibus renitentem, decollauit'.

75 AA, 56-57; John 10:12.

$76 A A, 56-59$ : 'Hic manus Domini contra peregrinos esse creditur, qui nimiis immundiciis et fornicario concubitu in conspectu eius peccauerunt, ex exules Iudeos licet Christo contrarios, pecunie auaricia magis quam pro iusticia Dei graui cede mactauerant, cum iustus iudex Deus sit, et neminem inuitum aut coactum ad iugum fidei Catholice iubeat uenire'. The events in Hungary judge their earlier pogroms.

$77 A A, 58-59$ : 'Fuit et aliud scelus desestabile in hac congregatione pedestris populi stulti uesane leuitatis, quod Deo odibile et omnibus fidelibus incredibile esse non dubitatur [...] Sed quid mirum si modernis temporibus huiuscemodi abhominationes, et tam feda scelera inter aliquas societates tot milium inuenta sunt, que Dominus Deus in caput eorum reddiderit, cum temporibus Moysi et Iosue et ceterorum seruorum Dei in medio iustorum inuenta est iniquitas, et ab eo qui est Deus ultionum uirga sue maiestatis correpta et purificata?' Note Albert concluding with a rhetorical question.

78 Diplomata Hungariae antiquissima, ed. Georgius [György] György (Budapest: Hungarian Academy of Sciences, 1992), vol. 1, 319-321; the correspondence is also questioned in László Veszprémy, Lovagilág Magyarországon: Lovagok, keresztesek, hadmérnökök a középkori Magyarországon (Budapest: Argumentum, 2008), 83. 
79 Godfrey's comment: $A A, 62-63$ : 'Quapropter nunc timore et dubietate concussi, Tollenburch moram facere decreuerunt, donec ex ore regis intelligant, cur tam crudele facinus a Christianis Christianorum presecutoribus commissum sit'; it is unlikely that Albert, or a source, witnessed 'Respondit rex uniuerso cetu suorum audiente', which begins Coloman's reply, 62-65.

$80 A A, 64-71$; 66: 'Hiis auditis dux uoluntati regis in omnibus cessit, et obsides quod petebat dare non abnuit, hac tamen conditione, ut ultra peregrinorum exercitus, tam presens quam futurus per terram eius transiret sine aliquo obstaculo, et pacifice mutuaret uite necessaria'; 68: 'exercitus Dei'.

81 Jonathan Riley-Smith, 'The Motives of the Earliest Crusaders and the Settlement of Latin Palestine, 1095-1100', English Historical Review 98 (1983): 721-36 (here 721).

82 AA, 306-7: 'Diuersi diuersa super hac sentiunt uia. Alii dicunt a Deo et Domino Iesu Christo hanc in omnibus peregrinis suscitatam uoluntatem, alii pro leuitate animi hanc Francigenas primores et plurimum uulgus insistere, er ob hoc in regno Vngarie et aliis in regnis tot peregrinis occurrisse impedimenta, nec ideo intentionem illorum ad effectum posse pertingere.'

83 AA, 306-9: 'Non leuitate aut gratis huius uie credas fuisse exordium, sed a Deo cui nihil impossible est dispositum, et procul dubio inter martyres Christi in celi aula noueris eos computatos, ascriptos et feliciter coronatos, quicumque in hac uia morte preoccupati fuerint, qui in nomine Iesu exules facti, puro et integro corde in dilectione Dei perseuerauerint, et se ab auaricia, furto, adulterio, fornicatione continuerint'.

84 Gérard Gennete, Narrative Discourse: An Essay in Method, tr. Jane E. Lewin (New York: Cornell University Press, 1983), 40, defining analepsis.

$85 A A, 586-587$.

86 See footnote 29.

$87 H V V, 24-25, \ln 1-14$.

$88 H V V, 24-27, \ln 15-32$.

$89 H V V, 26-29, \ln 33-50$.

$90 H V V, 28-29, \ln 51-78$.

$91 H V V, 28-29, \ln 79-90$

$92 H V V, 42-43, \ln 1-8$.

$93 H V V, 42-49, \ln 9-122 ; 6-7 \ln 71-74$, Godfrey had been presented as a key figure of the enterprise, having had the patriarch of Jerusalem petition him directly for support.

$94 H V V, 44-45$, ln 67-68: 'Nec pretiosarum gazarum querere templa / Sed pia, sed pura, sed amara innoxia corda.'

$95 H V V, 48-51, \ln 123-151$.

$96 H V V, 50-51, \ln .152-168$.

$97 H V V, 52-53$, ln 169-174: 'Hinc pretergressi uestigia longaque mensi, / Per que pertulerant memorata pericula primi, / Discunt quid ualeat moderatio consiliumque, / Contra quid noceat temeraria causa furorque, / Cum modo seruitio sibi sint et subditioni / Qui fuerant illis inhonestae perditioni.'

98 Investigation into manuscript variants may reveal more precise information about the reception of events in Hungary. 